\title{
Materiales de construcción incompatibles dentro de las esculturas estereotómicas de Avalos en el Valle de Caídos (Madrid, España)
}

\section{Incompatible building materials within the stereotomic Avalos's sculptures of the Valley of Fallen (Madrid, Spain)}

\author{
J. Garcia-Guinea $(*)$, G. Almendros ${ }^{(*)}$, D. Benavente(**), V. Correcher(***), A. Pérez-García(****), \\ L. Recio-Vázquez(*), S. Sánchez-Moral(*)
}

Recepción/Received: 22-XI-11

Aceptación/Accepted: $15-\mathrm{II}-12$

Publicado online/Online publishing: 6-III-12

RESUMEN

El estudio de una apertura abierta recientemente en la parte posterior cabeza de la escultura de la Piedad de Avalos confirma que está recubierta por placas de caliza negra de Calatorao (CNC) de unos $20 \mathrm{~cm}$ de espesor sujetas con morteros de yeso sin áridos. El análisis de estas muestras de morteros mediante microscopía óptica (MO), difracción de rayos X (DRX) y Microscopía Electrónica de Barrido Ambiental con Espectroscopia de Dispersión de Energías dispersivas de rayos X (MEBA-EDS) muestra mezclas de portlandita, mirabilita, etringita, taumasita y yeso, es decir, fases hidratadas bien conocidas por ser peligrosas para una adecuada preservación del patrimonio arquitectónico. Las gigantescas estructuras estereotómicas de Avalos están abiertas a las aguas de lluvia llegando a alcanzar sus núcleos de hormigón, que tienen áridos de granitos con feldespatos alcalinos alterados que están aportando sodio al ambiente sulfatado formando nuevos sulfatos cálcicos y sódicos hidratados como etringita y mirabilita que limitan la cohesión de los granos entre sí.

Palabras clave: deterioro; ataque por sulfatos; hormigón; etringita; yeso.

\section{SUMMARY}

Incompatible building materials within the stereotomic Avalos's sculptures of the Valley of Fallen (Madrid, Spain) The examination of the recently open pit in top of head of the Piety sculpture of Avalos confirms that the external outer of Black Limestone Calatorao (BLC) composite is made by slabs $20 \mathrm{~cm}$ thick joined with gypsum mortars without aggregates. The analyses of these mortars samples performed by optical microscopy (OM), X-ray diffraction (XRD) and Environmental Scanning Electron Microscopy with Energy Dispersive Spectrometry (ESEMEDS) techniques show hydrous admixtures composed by portlandite, mirabilite, ettringite, thaumasite and gypsum, all of them are well-know dangerous phases for a suitable preservation of the architectural heritage. The huge stereotomic structures have open access to the raining waters reaching the internal core of the sculptures made by concrete with weathered alkali-feldspar aggregates providing sodium to the surrounding sulfated environment facilitating the formation of hydrous calcium and sodium sulfates such as ettringite and mirabilite which reduces the inter-grains adherence.

Keywords: deterioration; sulphate attack; concrete; ettringite; gypsum.

\footnotetext{
(*) Museo Nacional de Ciencias Naturales (CSIC) (Madrid, España).

(**) Universidad de Alicante, Unidad Asociada UA-CSIC (Alicante, España).

(***) CIEMAT (Madrid, España).

${ }^{(* * *)}$ Universidad de Zaragoza (Zaragoza, España).
} 


\section{INTRODUCCIÓN}

El Valle de los Caídos (El Escorial, Madrid) contiene un grupo monumental de construcciones de gran tamaño edificadas desde 1940 hasta 1959 en un entorno de bosque de pinos de gran belleza natural. El edificio más destacado del complejo es una gran cruz de 150 metros de altura levantada sobre una colina de granito de 150 metros que resulta visible a 40 kilómetros de distancia. Las dimensiones de la Basílica subterránea son superiores a las de la Basílica de San Pedro del Vaticano en Roma. Un tren funicular conecta el nivel de base de la Basílica con la base de la cruz. El grupo tiene nueve esculturas de unos 20 metros de altura, ocho de ellas en la base de la enorme cruz. Fueron esculpidas por Juan de Ávalos, con núcleos de hormigón forrados por bloques de piedra caliza negra de Calatorao unidos por yeso, todos ellos mostrando huellas de meteorización muy visibles. La escultura de La Piedad es más pequeña, representa a Jesucristo y la Virgen y está colocada encima de la puerta principal de la Basílica (Figuras 1, 2). El complejo del Valle de los Caídos, siempre mantenido por Patrimonio Nacional de España, cerró el recinto a finales de 2009 para restaurar la escultura de la Piedad y evitar la caída de piedras sobre los visitantes. La posición sobresaliente de una parte de la Piedad y sus fracturas representaban una amenaza real. En abril de 2010 los técnicos de Capa Escultores abrieron la cabeza de la Piedad con sierras de diamante y el autor GarcíaGuinea pudo hacer un muestreo interno. Observando

\section{INTRODUCTION}

The Valley of the Fallen (Escorial, Madrid, Spain) is a huge monumental memorial built from 1940 to 1959. The most prominent building of the monument is the towering 150-meter-high Cross erected over a granite outcrop 150 meters over the Basilica's esplanade being visible from $40 \mathrm{~km}$ away. The dimensions of the underground Basilica are quite larger than those of St. Peter's Basilica in Rome. A funicular train connects the Basilica level with the cross basement. Nine monumental sculptures up to 20 meters tall are over the main gate and the basement of the huge cross. They were built by the Juan de Avalos sculptor with concrete cores covered with black-limestone Calatorao slabs joined with gypsum, all of them exhibiting nowadays evident weathering traces. The Piety sculpture representing Jesus Christ and Madonna was placed at the top of the main gate of the Basilica. The built complex is kept by the official Spanish National Heritage Agency which closed the architectonic complex at the end of 2009 to restore the Piety sculpture to prevent stone falls on the tourists. The overhanging position of a part of the Piety sculpture drops dangerous weathered stone flakes and fragments (Figures 1 and 2). In April 2010, the Piety sculpture top was opened with diamond saws to be explored by Capa Sculptor technicians of the National Heritage keepers and author Garcia-Guinea collected internal samples. The weathering paradigms of these huge stereotomic sculptures are not well defined in terms of physical-chemical processes; consequently,

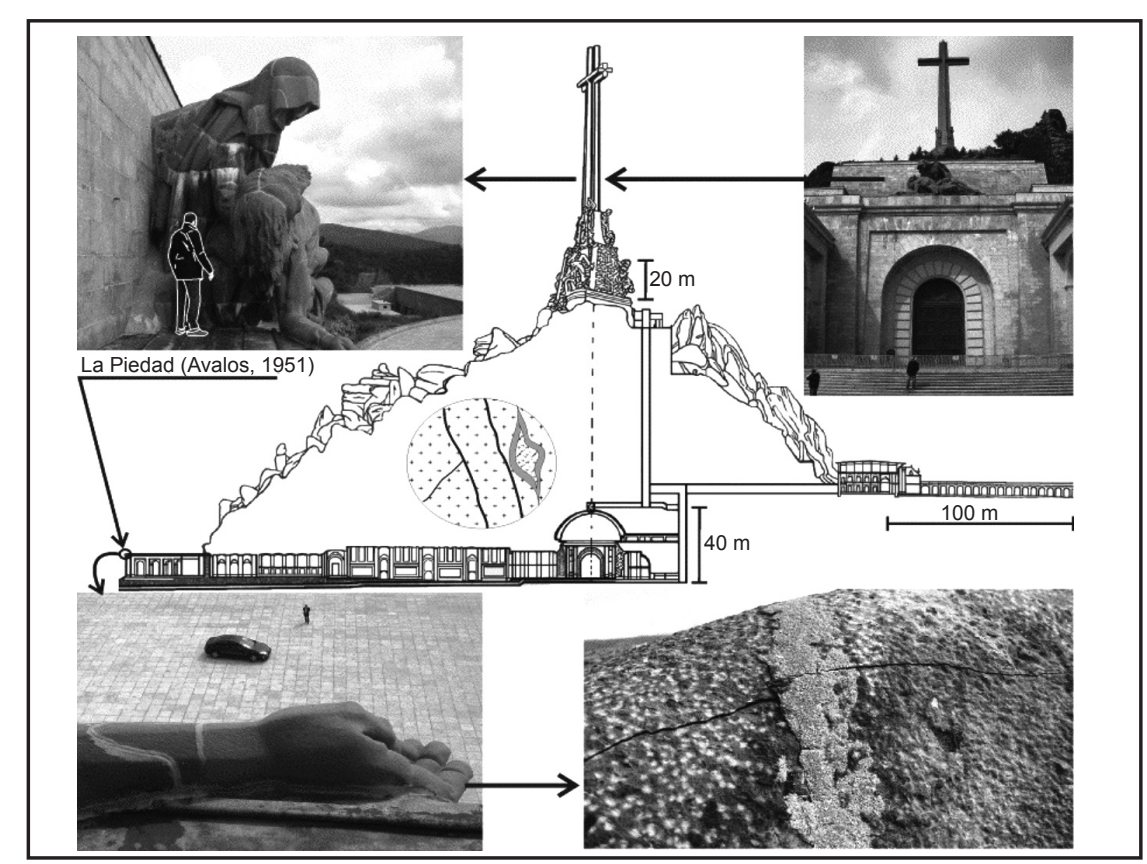

Figura 1. Detalles de la escultura de La Piedad, como eflorescencias, posición extraplomada de un brazo de Jesús sobre la entrada de la Basílica, caliza de Calatorao fisurada a pesar de una consolidación previa con epoxi. La Piedad se erosiona soltando peligrosos fragmentos de roca.

Figure 1. Details of La Piety Sculpture such as efflorescences, overhanging position of a Jesus arm, Basilica main door and fissured BLC despite of the former epoxy consolidation. La Piety sculpture drops dangerous flakes and fragments of weathered stone. 


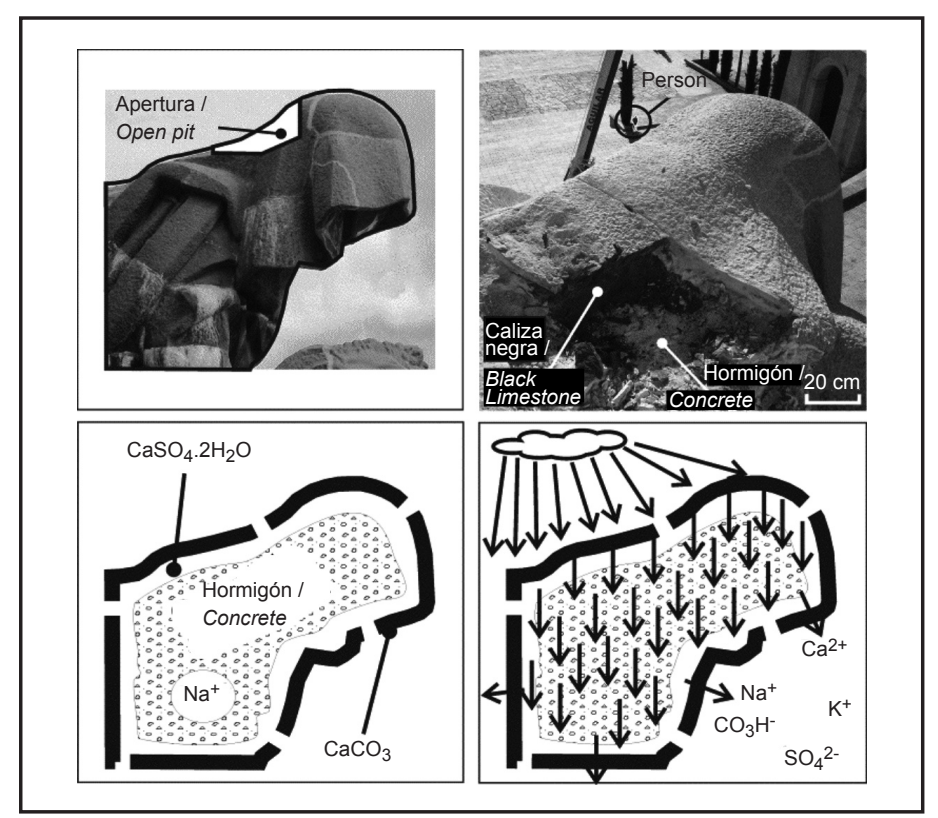

Figura 2. Detalles del agujero realizado sobre la cabeza de la escultura de la Piedad, materiales internos y resumen de los procesos de meteorización del sistema.

Figure 2. Details of the open pit in La Piety Sculpture, internal geomaterials and weathering processes summary.

los materiales internos hicimos las siguientes consideraciones sobre las esculturas: (i) están situadas en una zona de clima continental sin contaminación, (ii) son estereotómicas y gigantescas, alcanzando los 19 metros de altura, (iii) están montadas con materiales incompatibles sobre un núcleo de hormigón recubierto de placas de caliza de Calatorao, cementadas con yeso y masilla de cal, (iv) el hormigón mostraba áridos de leuco-adamellita y arena arcósica, es decir, feldespatos sódicos y alcalinos, (v) la propia complejidad intrínseca de la piedra caliza de Calatorao con sulfuros de hierro, cuarzo, filosilicatos y materia orgánica, (vi) de la procedencia de piedra caliza de las canteras de Calatorao (Zaragoza). La CNC es una biomicrita fosilífera con macrofósiles, filosilicatos, cuarzo, sulfuros de hierro y materia orgánica. Los morteros de sulfatos liberan iones $\left(\mathrm{SO}_{4}{ }^{2-}\right)$ y Ca2+ los que junto con los grupos $\mathrm{H}_{3} \mathrm{O}^{+}$ de aguas ácidas que pueden disolver tanto los hidroalumino-silicatos del hormigón como los feldespatos de los áridos (1-3). La formación de sulfato de sodio en una superficie de cemento indica ataque de sulfatos en el interior del hormigón (4-6). Las muestras del interior de la Piedad fueron analizadas por MO, MEBA-EDS y DRX para estudiar los procesos de meteorización. Este trabajo estudia la estructura interna de las esculturas, la composición de sus materiales internos y las causas de las alteraciones, analizando supuestos de futuras restauraciones. the Valley shutting was misinterpreted in the Spanish Media. Our first view of the internal materials and surroundings offered the following remarkable features: (i) Clean environmental conditions in continental climate, (ii) Huge size of the stereotomic sculptures reaching up to $19 \mathrm{~m}$ high, (iii) A mixed composition of the sculpture body formed by a concrete core covered by black-limestone slabs joined with gypsum and limeputty, (iv) Concrete core composed by leuco-adamellite aggregates and arkose sand, i.e., sodium-feldspars, (v) Intrinsic complexity of the Calatorao limestone, with iron sulphides, quartz, phyllosilicates and organic matter, (vi) A limestone provenance from the Calatorao quarries (Zaragoza). These quarries were the original source of the Black-Limestone Calatorao (BLC) slabs which cover the Valley of the Fallen sculptures, BLC are fossiliferous biomicrites rocks with macrofossils containing also noncalcareous components as quartz, phyllosilicates, iron sulfides and organic matter. The use of gypsum mortars in outdoor environments release sulfate $\left(\mathrm{SO}_{4}^{2-}\right)$ and $\mathrm{Ca}^{2+}$ which together with hydronium $\left(\mathrm{H}_{3} \mathrm{O}^{+}\right)$ions from acid waters could dissolve both, the hydro-alumino-silicates of the hardened cement, and the alkali feldspar of the concrete aggregates (1-3). The formation of sodium sulfate on a concrete surface is an indication of sulfate attack occurring in the interior of the concrete (4-6). The internally collected samples from the Piety sculpture were analyzed by OM, ESEM-EDS and XRD techniques to understand the weathering traces. This work is focused to the study of the internal structure of sculptures, materials composition, weathering traces and causes and possible further restoration actions. 


\section{EXPERIMENTAL}

El día 24 de abril de 2010 se procedió al muestreo del interior de la cabeza de La Piedad, practicando una apertura con sierra de diamante. Las muestras eran calizas negras (CNC), morteros blancos, fragmentos de hormigón, algún resto metálico y resinas epoxi de restauraciones anteriores (Figuras 2 y 3 ). Las secciones delgado-pulidas de 35 micras de las muestras fueron estudiadas en un microscopio de polarización (Nikon Eclipse C600 POL) y en un microscopio MEBA-EDS para analizar morfologías, texturas, sistemas de poros, composición, forma de los cristales y tamaños de elementos accesorios en la piedra caliza como pirita, cuarzo, microfósiles, óxidos de hierro, fibras de etringita, rellenos de poros, etc. El equipo de MEBA-EDS utilizado es un FEI Quanta operando a bajo vacío que permite operar a alta resolución haciendo análisis químicos por EDS de muestras no conductoras a los electrones. Funcionando en este modo de bajo vacío se pueden estudiar sales hidratadas sin metalizar. El equipo tiene sonda de electrones retro-dispersados (BS) y espectrómetro de energía dispersiva de rayos X (EDS). La identificación mineralógica de muestras pulverizadas fue realizada por DRX en un difractómetro de X'Pert PRO MPD usando radiación CuK $\alpha$ de $5^{\circ}$ a $80^{\circ} 2 \theta$, con un salto

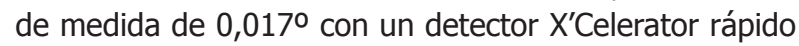
y una rendija de divergencia de $1 / 8^{\circ}$, es decir, 11 minutos por cada perfil de difracción de rayos $\mathrm{X}$, filtro de $\mathrm{Ni}$ secundario sin monocromador. Los análisis semicuantitativos de los residuos insolubles de silicatos, obtenidos por ataque ácido clorhídrico de las calizas, se llevaron a cabo por DRX de: (i) polvo desorientado seco, (ii) agregados orientados tratados con etilen-glicol durante $4 \mathrm{~h}$ por el método de presión de vapor, y (iii) agregados orientados calentados a durante $30 \mathrm{~min}$ a $400{ }^{\circ} \mathrm{C}$ y 90 $\min$ a $550^{\circ} \mathrm{C}$.

\section{RESULTADOS Y DISCUSION}

\subsection{Estructura interna de la escultura de La Piedad: morteros de sulfatos y hormigón}

La inspección de la Piedad (Figura 1) nos permitió identificar una gran eflorescencia formando espeleotemas de $\mathrm{CaCO}_{3}$ y fisuras abiertas afectando a otras fisuras anteriores selladas con mezclas de epoxi-cuarzo, todo ello en una posición física de la escultura de la Piedad extraplomada muy peligrosa justo encima de la entrada a la Basílica. El nuevo boquete abierto (Figura 2) nos permitió recoger muestras internas (Figura 3 ) de las distintas secciones: (i) eflorescencias de $\mathrm{CaCO}_{3}$, (ii) placas de CNC, (iii) zona intermedia de unión de yeso y otros sulfatos (iv) núcleo interno de hormigón de cemento con

\section{EXPERIMENTAL}

Samples of black limestone, gypsum, mortar and concrete were collected during the restoration works performed on the top of The Piety sculpture at April, 24th, 2010 with the support of a huge tow truck and climbing equipment (Figures 2, 3). The restoration operations in the statue lead us to identify litho-types, recognize decay forms and evaluate the degree of deterioration. The mineralogy and texture of samples were analyzed on cut-polished thin sections up to $35 \mu \mathrm{m}$ in thickness, under a polarizing microscope (Nikon Eclipse C600 POL) and a ESEM microscope to analyze the morphology, textures, pore system, composition, crystal shapes and sizes of limestone items such as calcite crystals, pyrite, quartz grains, microfossils as shell fragments, iron oxides, ettringite fibers, vesicle fillings, etc. The ESEM FEI Quanta used equipment is a low-vacuum scanning electron microscope which enables high-resolution inspection and chemical analysis of non-conductive specimens. Operating in low vacuum mode it admits hydrated samples to be studied in their original state without metallization. It has back-scattering (BS), Energy Dispersive Spectrometer (EDS) and Cathodoluminescence (CL) probes coupled to the system. The structural analyses of powdered samples were performed by XRD with an $X$ 'Pert PRO MPD diffractometer using $\mathrm{Cu} K \alpha$ radiation from $5^{\circ}$ to $80^{\circ} 2 \theta$, with a scan step size of 0.0170 using a fast X'Celerator detector with a divergence slit of $1 / 8^{\circ}$, (i.e., 11 min per XRD profile, with secondary Ni filter and without a mono-chromator). The semi-quantitative analyses of the minor amounts of phases included in the limestone rock, previously extracted by HCI acid attach, were also performed by XRD on: (i) disoriented powder air dried, (ii) oriented preparations treated with ethylene glycol for four hours by the vapour pressure method, and (iii) oriented preparations heated for $30 \mathrm{~min}$ at $400{ }^{\circ} \mathrm{C}$ and $90 \mathrm{~min}$ at $550^{\circ} \mathrm{C}$.

\section{RESULTS AND DISCUSSION}

\subsection{Internal structure of The Piety sculpture: sulfates and concrete}

The near revision of The Piety sculpture (Figure 1) let us to identify a strong white efflorescence formed by $\mathrm{CaCO}_{3}$ speleothems together with open fissures affecting other previous sealed fissures with epoxy-quartz mixtures and placed in a dangerous over-hanged position of part of the Piety sculpture just on the top of the Basilica main gate. The restoration action performed on The Piety sculpture (Figure 2) let us to collect very dissimilar specimens (Figure 3) from the different sections, as follows: (i) external calcium carbonate efflorescence, (ii) external cover formed by BLC, (iii) intermediate join of gypsum 
A)

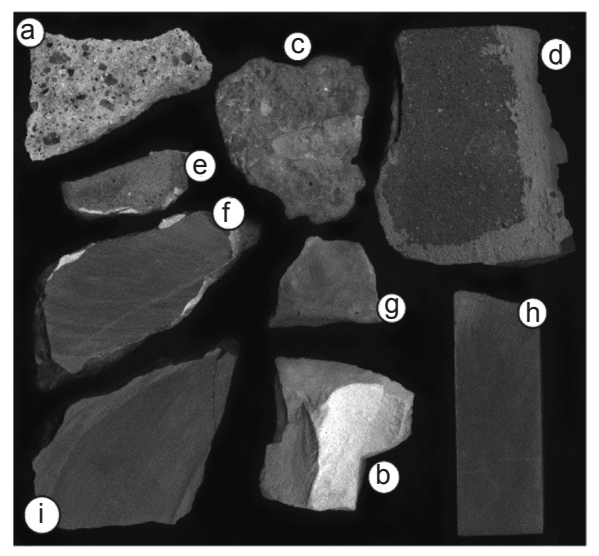

Tabla 1 / Table 1

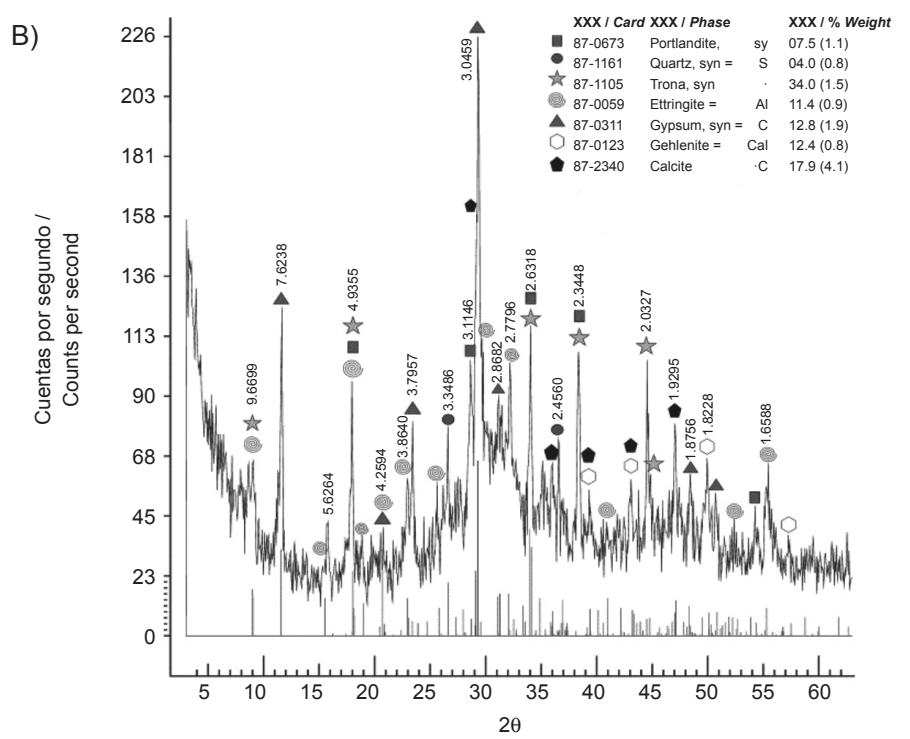

Figura 3. (a) Nueve muestras recogidas en el interior de la escultura de La Piedad analizadas por difracción de rayos X. Se trata de calizas de Calatorao, hormigón meteorizado, sulfatos y carbonatos hidratados, y fragmentos de mezclas de unión epoxi-cuarzo. La Tabla 1 muestra los respectivos porcentajes de minerales de cada muestra. (b) Difractograma de la muestra de mortero-b con asignaciones y porcentajes de fases determinadas mediante el software español Xpowder.

Figure 3. (a) Nine stones collected in the La Piety inside analyzed by semi-quantitative X-ray diffraction. They are Calatorao limestone, weathered concrete, hydrous sulphates and carbonates of the sulfate join blend and epoxy-quartz fragments. Table 1 displays mineral percentages by each sample. (b) XRD pattern of a mortar-b sample including the phase assignations and percentages determined using the Spanish software Xpowder.

áridos de granito leucoadamellitico sódico. Los análisis por DRX evidenciaron que el interior de la Piedad tiene fases hidratadas, tanto en el núcleo de hormigón como en los morteros. La Figura 3-Tabla 1 muestran una tabla de distribución de porcentajes de fases mineralógicas de cada muestra realizada mediante análisis semicuantitativos de DRX utilizando el programa informático español XPowder. Las fases se determinaron aplicando sustracción de fondo, eliminación de picos $\mathrm{K} \alpha 2$ y restricciones sobre elementos previamente determinados por MEBAEDS, es decir, Na, Mg, Al, Si, P, S, K, Ca, Ti, Fe. Estas características mejoraron las búsquedas de coincidencias booleanas en las bases de datos ICDD-PDF2 y RRUFF sugiriendo estas fichas PDF2: and (iv) internal concrete core made of cement and leuco-adamellite granite aggregates with sodium feldspars. The analysis of these powdered samples by X-ray diffraction shows as the Piety sculpture inner contains hydrous phases in both concrete and joins. Figure 3 Table-1 also display a table of the percentages distribution of mineralogical phases for each sample performed by semi-quantitative XRD analyses using Spanish Xpowder software. Phases were identified performing background subtraction, Ko2 stripping and chemical elements restraining to the major elements previously determined by ESEM-EDS, i.e., Na, Mg, Al, Si, P, S, K, Ca, Ti, Fe. These features improve the Boolean search-matching on the ICDD-PDF2 and RRUFF databases suggesting PDF2 card files, as follows: 
1) Hormigón: 79-1906 Cuarzo $\left(\mathrm{SiO}_{2}\right)$; 79-2334 Calcita $\left(\mathrm{CaCO}_{3}\right) ; 79-0814$ Moscovita 2/1TM $\left(\mathrm{KAl}_{2}\left(\mathrm{Si}_{3} \mathrm{Al}\right)\right.$ $\left.\mathrm{O}_{10}(\mathrm{OH})_{2}\right)$; 79-8574 Feldespato sódico $\left(\mathrm{NaAlSi}_{3} \mathrm{O}_{8}\right)$; 79-0710 Feldespato potásico $\left(\mathrm{KAlSi}_{3} \mathrm{O}_{8}\right) ; 79-0059$ Etringita $\left(\mathrm{Ca}_{6} \mathrm{Al}_{2}\left(\mathrm{SO}_{4}\right)_{3}(\mathrm{OH})_{12} \cdot 26 \mathrm{H}_{2} \mathrm{O}\right)$.

2) Morteros sulfatados-carbonatados: 87-0673 Portlandita $\mathrm{Ca}(\mathrm{OH})_{2} ; 87-1105$ Trona $\mathrm{Na}_{3}\left(\mathrm{CO}_{3}\right)\left(\mathrm{HCO}_{3}\right)$ $\cdot 2\left(\mathrm{H}_{2} \mathrm{O}\right) ; 87-0311$ Yeso $\left(\mathrm{CaSO}_{4} \cdot 2 \mathrm{H}_{2} \mathrm{O}\right) ; 87-2340$ Gehlenita $\left(\mathrm{Ca}_{2} \mathrm{Al}(\mathrm{AlSi}) \mathrm{O}_{7}\right)$; 87-2340 Calcita $\left(\mathrm{CaCO}_{3}\right)$.

Las fases hidratadas portlandita, trona, etringita y yeso que "unen" las placas de CNC se han formado por sucesivas acumulaciones de agua entre las losas de caliza $\left(\mathrm{CaCO}_{3}\right)$ y el mortero antiguo de yeso $\left(\mathrm{CaSO}_{4} \cdot 2 \mathrm{H}_{2} \mathrm{O}\right)$. Estas fases, que fueron identificadas por DRX, MO y MEBA-EDS en el interior de la escultura, están destruyendo la cobertera exterior de bloques de CNC produciendo eflorescencias, caídas de fragmentos y placas. El presente estudio comenzó estudiando bloques de CNC con escasas conclusiones novedosas, sin embargo la posterior oportunidad de muestrear el interior de la escultura podía aportar datos clave sobre la composición de los morteros y hormigones del interior. Por ejemplo, los hormigones tienen áridos del granito local, muy rico en sodio además de los peligrosos sulfatos utilizados como morteros para pegar los bloques de CNC al núcleo de hormigón. Bajo el microscopio óptico de polarización, las secciones delgadas de unas 35 micras de las muestras del interior de la escultura mostraban lo siguiente: Figura 4a. Especimen de CNC con fragmentos alargados de conchas $\left(\mathrm{CaCO}_{3}\right.$ puro), áreas en negro de kerógeno, una grieta rellena de calcita de esquina a esquina; Figura 4b. El núcleo de hormigón contiene agregados de granito leuco-adamellítico, incluyendo los componentes característicos de granito tensionados, placas de biotita con inclusiones de circón, microclinas con texturas de exsoluciones-maclados, plagioclasas con maclas polisintéticas, etc., un fenocristal de feldespato alcalino alterado a caolinita-illita, como ejemplo de lixiviación de feldespatos emitiendo potasio y sodio al medioambiente. La Figura 4c muestra una biotita más fresca en el granito del árido del hormigón en la misma sección. La Figura 4d muestra una sección petrográfica de la matriz de hormigón con una burbuja rellena con cristales de etringita, algunas imágenes muy parecidas a estas se observaron también en el mortero sulfatado. Las mismas muestras analizadas por DRX muestran diferentes proporciones de etringita, yeso, portlandita y trona, todas ellas son fases hidratadas neo-formadas. Las imágenes de MEBA de estas mezclas de la muestra de mortero blanco mostraban dos tipos diferentes de masas de agujas (Figura 5a): (i) grupos de cristales de alrededor de 10 a 40 micras y (ii) cristales submicrométricos formando masas homogéneas. Bajo MEBA-EDS estos cristales alargados muestran importantes cantidades de $\mathrm{Al}_{2} \mathrm{O}_{3}, \mathrm{CaO}$ y $\mathrm{SO}_{3}$ e impurezas de cuarzo, cobre, plomo y estaño (Figura 6-Tabla 2). El
1) Concrete sample: 79-1906 Quartz ( $\left.\mathrm{SiO}_{2}\right)$; 792334 Calcite $\left(\mathrm{CaCO}_{3}\right)$; 79-0814 Muscovite 2/1TM $\left(\mathrm{KAl}_{2}\left(\mathrm{Si}_{3} \mathrm{Al}\right) \mathrm{O}_{10}(\mathrm{OH})_{2}\right) ; 79-8574 \mathrm{Na}$-Feldspar (NaAl$\left.\mathrm{Si}_{3} \mathrm{O}_{8}\right) ; 79-0710 \mathrm{~K}$-Feldspar $\left(\mathrm{KAISi}_{3} \mathrm{O}_{8}\right) ; 79-0059$ Ettringite $\left(\mathrm{Ca}_{6} \mathrm{Al}_{2}\left(\mathrm{SO}_{4}\right)_{3}(\mathrm{OH})_{12} \cdot 26 \mathrm{H}_{2} \mathrm{O}\right)$.

2) White mortar sample: $87-0673$ Portlandite $\mathrm{Ca}(\mathrm{OH})_{2}$; 87-1105 Trona $\mathrm{Na}_{3}\left(\mathrm{CO}_{3}\right)\left(\mathrm{HCO}_{3}\right) \cdot 2\left(\mathrm{H}_{2} \mathrm{O}\right) ; 87-0311$ Gypsum (CaSO4.2H2O); 87-2340 Gehlenite $\left(\mathrm{Ca}_{2} \mathrm{Al}(\mathrm{AlSi}) \mathrm{O}_{7}\right) ; 87-2340$ Calcite $\left(\mathrm{CaCO}_{3}\right)$.

The hydrous phases portlandite, trona, ettringite and gypsum joining the BLC slabs obviously are being produced under strong wet conditions among the limestone slabs $\left(\mathrm{CaCO}_{3}\right)$ and the probable former mortar $\left(\mathrm{CaSO}_{4} \cdot 2 \mathrm{H}_{2} \mathrm{O}\right)$. These phases, detected by XRD, OM and EDS in the sculpture inner help to destroy the external cover of BLC producing efflorescence, flaking and fall down of fragments. We started our research on the composition and porosity of the external BLC slabs, furthermore, the physical collection of internal samples of mortar and concrete revealed new crucial data of the concrete core composition including the granite aggregates, as sodium suppliers in addition to the inferred calcium sulfate, which must be used to join the concrete core with the limestone blocks. The petrographic thin sections of samples collected from the The Piety sculpture inner revealed interesting data under the optical polarizing microscope, as follows: Figure 4a shows BLC sample displaying shell fragments as sticks (pure $\mathrm{CaCO}_{3}$ ), black areas of kerogen, a fissure filled by calcite from the top-right to bottom-left corners; The concrete core contains aggregates of leuco-adamellite granite, including the characteristic components of strained quartz, biotite platelets with zircon inclusions, hatch-cross twined microclines, polysynthetic twinned plagioclase, etc. Figure $4 b$ shows a phenocrystal of alkali feldspar weathered to kaolinite phases; this is a good example of leached feldspar which leak out alkaline cations, such as potassium and sodium under weathering. Figure $4 c$ shows a better preserved biotite phase of the granite concreteaggregate taken from the same section. Figure $4 d$ shows a petrographic thin section of the concrete matrix exhibiting a former bubble stuffed with ettringite crystals. This same image was observed from the weathered sulfated joins; samples analyzed by XRD exhibit different mixtures of ettringite, gypsum, portlandite and trona, all of them neo-formed hydrous phases. The ESEM images of these mixtures of the white mortar sample showed two different types of needles masses (Figure 5a), as follows: (i) crystals groups sized from circa 10 to $40 \mu \mathrm{m}$ and (ii) micro-crystals sized under the micron forming homogeneous masses. The EDS-ESEM analyses of these masses of spiked crystals displayed important amounts of $\mathrm{Al}_{2} \mathrm{O}_{3}$, $\mathrm{SO}_{3}$ and $\mathrm{CaO}$ and minor impurities of quartz grains and native copper, lead and tin metals (Figure 6, Table 2). The comparative $\mathrm{Al}_{2} \mathrm{O}_{3}-\mathrm{SO}_{3}-\mathrm{CaO}$ ternary plot (Figure 6 right) 


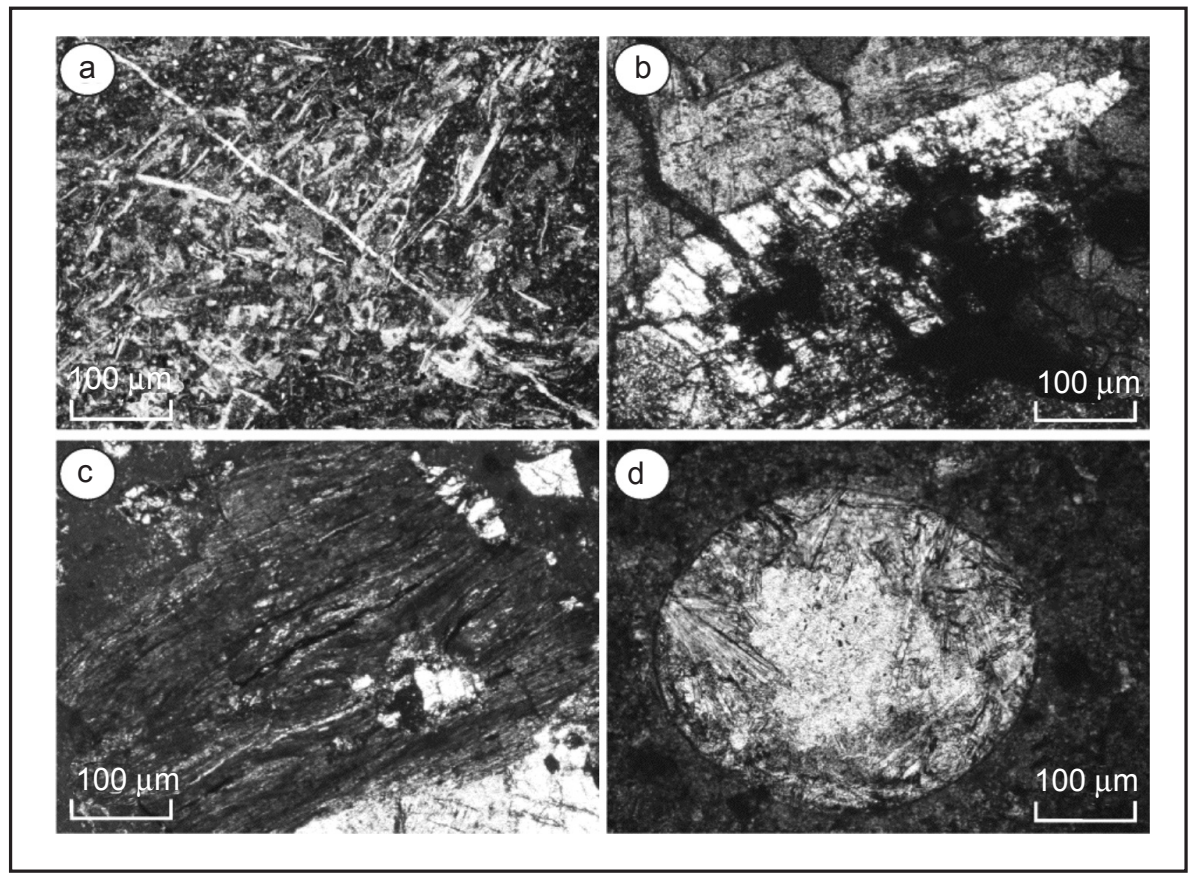

Figura 4. Secciones de $35 \mu \mathrm{m}$ de las muestras bajo el microscopio de polarización: (a) Caliza negra en Calatorao compuesta por fragmentos de conchas y materia orgánica oscura. (b) Feldespato alterado en los áridos del núcleo de hormigón. (c) Biotita en los áridos de granito. (d) Espacio de una antigua vacuola ahora rellena de fibras de etringita.

Figure 4. Slices of $35 \mu \mathrm{m}$ of the collected specimens under the polarizing microscope: (a) Calatorao limestone mainly composed by calcite shells and black kerogen. (b) Weathered alkali feldspar of the concrete nucleus. (c) Biotite of the granite aggregates of the concrete. (d) Empty space of a former bubble nowadays stuffed with fibrous ettringite.

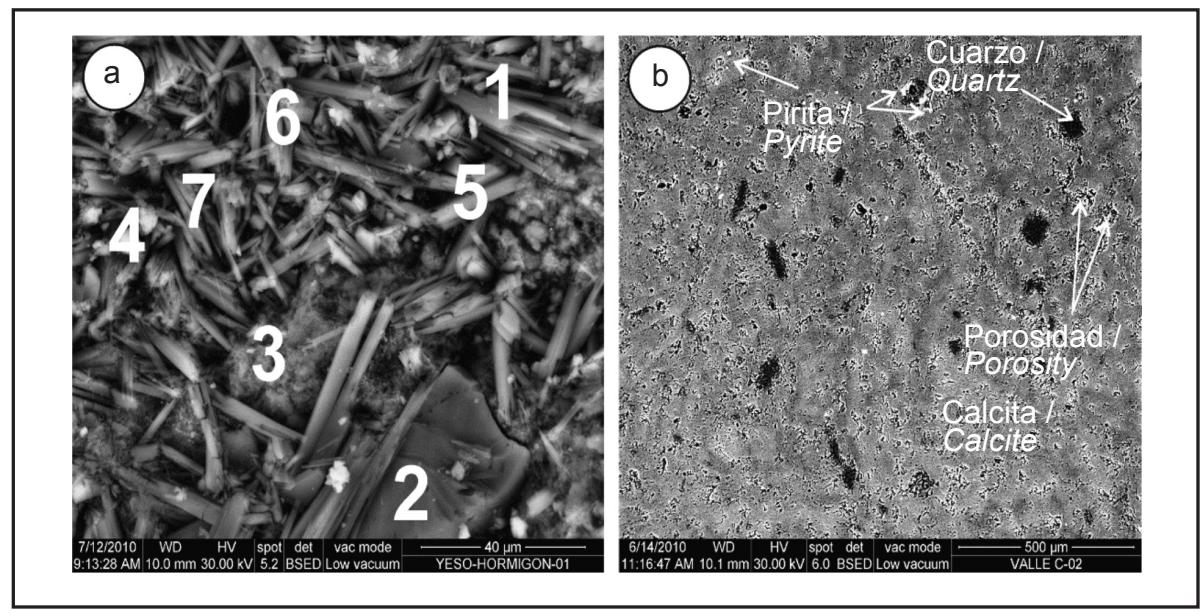

Figura 5. Imágenes de microscopía electrónica de barrido ambiental: (a) Aluminosilicatos hidratados y sulfatos aluminosos hidratados de diferentes composiciones, fundamentalmente taumasita y etringita. (b) Detalles de los granos de cuarzo, piritas oxidadas y porosidad de la caliza negra de Calatorao.

Figure 5. Environmental Scanning Electron Microscope images: (a) Hydrous silicates-aluminates-sulfates of different compositions, mainly thaumasite and ettringite. (b) Details of the quartz grains, pyrites and porosity of the black-limestone.

diagrama ternario $\mathrm{Al}_{2} \mathrm{O}_{3}-\mathrm{CaO}-\mathrm{SO}_{3}$ (Figura 6, derecha) permite clasificar el micro-análisis de las muestras de taumasita (inferida a partir análisis químico), yeso y etringita, junto con un grupo central de mezclas de etringita-taumasita-portlandita. Se puede concluir que tanto los morteros sulfatados como el núcleo de hormigón contienen cantidades importantes de fases hidratadas, como yeso, portlandita, trona, etringita y allow to separate different micro-sample spot analyses of quartz, inferred thaumasite, gypsum and ettringite together with a central group of different mixtures of ettringite-thaumasite-portlandite. The simple conclusion is that both, the sulfated joint and the concrete inner contain important amounts of hydrous phases such as gypsum, portlandite, trona, ettringite and normative thaumasite (inferred from the chemical analysis) being 
Tabla 2 / Table 2

(a) Análisis Microscopio Electrónico de Barrido / ESEM Anlayses

\begin{tabular}{|c|c|c|c|c|c|c|c|c|c|}
\hline & $\mathrm{M} 1$ & $\mathrm{M} 2$ & $\mathrm{M} 3$ & $\mathrm{M} 4$ & $\mathrm{M} 5$ & $\mathrm{M} 6$ & $\mathrm{M} 7$ & $\mathrm{M} 13$ & $\mathrm{M} 17$ \\
\hline $\mathrm{Na}_{2} \mathrm{O}$ & 0 & 0 & 0 & 0 & 0 & 0 & 0 & 0 & 1.69 \\
\hline $\mathrm{MgO}$ & 0 & 0 & 45 & 1.11 & 0 & 0 & 0 & 0 & 0 \\
\hline $\mathrm{Al}_{2} \mathrm{O}_{3}$ & 12.66 & 1.07 & 7.34 & 13.35 & 13.03 & 11.19 & 14.84 & 9.65 & 6.72 \\
\hline $\mathrm{SiO}_{2}$ & 394 & 90.85 & 22.71 & 18.10 & 4.68 & 3.14 & 3.70 & 10.03 & 37.38 \\
\hline $\mathrm{P}_{2} \mathrm{O}_{5}$ & 0 & 0 & 0 & 0 & 0 & 0 & 0 & 0 & 93 \\
\hline $\mathrm{SO}_{3}$ & 23.83 & 1.84 & 5.51 & 14.45 & 22.74 & 26.14 & 27.12 & 13.75 & 88 \\
\hline $\mathrm{K}_{2} \mathrm{O}$ & 0 & 0 & 58 & 26 & 0 & 0 & 0 & 0 & 44 \\
\hline $\mathrm{CaO}$ & 59.21 & 6.24 & 62.42 & 48.81 & 59.10 & 59.24 & 54.01 & 42.40 & 10.30 \\
\hline $\mathrm{TiO}_{2}$ & 0 & 0 & & 32 & 0 & 0 & 0 & 0 & 0 \\
\hline $\mathrm{Fe}_{2} \mathrm{O}_{3}$ & 37 & 0 & 99 & 3.61 & 45 & 30 & 33 & 41 & 25 \\
\hline $\mathrm{PbO}$ & 0 & 0 & 0 & 0 & 0 & 0 & 0 & 23.76 & 0 \\
\hline $\mathrm{CuO}$ & 0 & 0 & 0 & 0 & 0 & 0 & 0 & 0 & 35.38 \\
\hline $\mathrm{SnO}$ & 0 & 0 & 0 & 0 & 0 & 0 & 0 & 0 & 6.02 \\
\hline
\end{tabular}

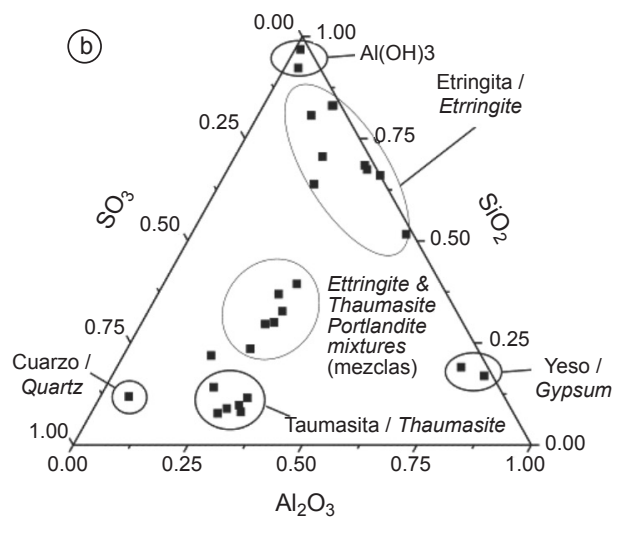

Figura 6. Distribuciones composicionales $\mathrm{SO}_{3}-\mathrm{SiO}_{2}-\mathrm{Al}_{2} \mathrm{O}_{3}$ de los análisis químicos EDS tomados sobre diferentes puntos de un mortero sulfatado, mostrando etringita y taumasita (inferidas a partir de análisis químicos). Tabla 2. Análisis EDS de masas de cristales aciculares mostrando importantes cantidades de $\mathrm{Al}_{2} \mathrm{O}_{3}, \mathrm{SO}_{3}$ and $\mathrm{CaO}$ con algunas impurezas de $\mathrm{Cu}, \mathrm{Pb}$ y $\mathrm{Sn}$ procedentes de los soportes metálicos cercanos de la escultura.

Figure 6. Compositional plot $\mathrm{SO}_{3}-\mathrm{SiO}_{2}-\mathrm{Al}_{2} \mathrm{O}_{3}$ with ESEM-EDS chemical analyses taken in a sulfated mortar exhibiting normative compositions of ettringite and normative thaumasite inferred from the chemical analysis. Table 2. EDS-ESEM analyses of the masses of spiked crystals displaying important amounts of $\mathrm{Al}_{2} \mathrm{O}_{3}, \mathrm{SO}_{3}$ and $\mathrm{CaO}$ and small impurities of $\mathrm{Cu}, \mathrm{Pb}$ and $\mathrm{Sn}$ from the sculpture metallic supports and neighboring roofs.

taumasita. El análisis semicuantitativo de DRX de muestra total de hormigón arroja un $37 \%$ de feldespatos alcalinos (Figura 3-Tabla 1). Esta gran cantidad de feldespato alcalino, tanto en los áridos como en la matriz, puede ser una fuente significativa de sodio y potasio en disolución. Estos elementos alcalinos en combinación con la substancial cantidad de sulfato analizada generan sales peligrosas para la preservación del patrimonio arquitectónico.

\subsection{Cobertera externa de las estatuas: bloques de caliza negra de Calatorao}

Bajo el microscopio de polarización, las secciones petrográficas de calizas CNC procedentes de las esculturas del Valle de los Caídos y de las canteras de Calatorao mostraron: (i) morfologías de conchas de calcita, materia orgánica, geles de hidróxido de hierro, sulfuros de hierro en forma de masas opacas, granos de cuarzo y masas de filo-silicatos; (ii) distribuciones irregulares de poros; (iii) calcitas de relleno de fisura. Desde el punto de vista petrográfico, estas calizas negras jurásicas son biomicritas caliza granular lodosa (ver Figura 4a). El análisis semicuantitativo por DRX de las muestras de CNC mostró fase calcita y cantidades accesorias de cuarzo desde 2 hasta $11 \%$. En Calatorao, los estratos de caliza negra contienen restos fósiles marinos, materia orgánica (kerógeno) y sulfuros de hierro, junto cuarzos detríticos alóctonos continentales. Las canteras de Calatorao solo producen pequeños bloques de hasta un metro cúbico, con porosidad moderada y fisuración rellena de calcita blanca y/o sulfuros de hierro oxidados. Las mediciones totally destroyed in the concrete section sampled. Moreover, it is important to note that the semi-quantitative $X R D$ analyses of the concrete sample show $37 \%$ of alkali feldspar (Figure 3-Table 1). This important amount of alkali feldspar in matrix and concrete aggregates is an important source of leachable sodium and potassium. These alkaline elements combined with the observed sulfates in the glued sculpture joints provide dangerous salts for the architectural heritage preservation.

\subsection{External envelope of the sculptures: black limestone Calatorao slabs}

Under polarizing microscope, the petrographic sections of several BLC samples from the Sculptures and from the Calatorao quarries showed the following features: (i) shell shapes of calcite, organic matter, iron hydroxide gels, iron sulfides, as opaque black masses, quartz grains and phyllo-silicate masses; (ii) irregular pore distribution, (iii) vein infill's of re-crystallized white calcite and iron oxides. From a petrographic point of view, these Jurassic black limestones can be defined as wackestonepackestone biomicrite (e.g., Figure 4a). The XRD semiquantitative analyses of BLC samples showed calcite phase but not dolomite, and quartz amounts from 2 to $11 \%$. The BLC beds enclose marine fossil remains, organic matter and iron sulphides together with an extrinsic contribution by continental quartz grains. The rocks yielded in the Calatorao quarries are small blocks up to one cubic meter sized, with moderate porosity, moderate fissures, calcite white veins and accessorial content of sulfur and organic matter. The pore measurements on 
de los poros en secciones de CNC muestran que tiene baja porosidad, de 2,45 a 0,19\% (Figura 5b). Estas características geotécnicas proporcionan una buena roca ornamental de calidad suficiente para usos arquitectónicos, esculturas, pavimentos o recubrimientos de paredes exteriores en climas templados. La comparación entre CNC original (cantera) y degradada (placa de la escultura de La Piedad), bajo el microscopio MEBA-EDS, muestra pirita, i.e., $\mathrm{S}$ y $\mathrm{Fe}$, en la CNC fresco (Figura 5 b) y solo $\mathrm{Fe}$ en CNC degradada, es decir, hidróxidos de hierro con formas características de pirita (pseudomórfica) framboidal formada en medios euxínicos. La forma redondeada de los granos de cuarzo y el tamaño de los poros de alrededor de 10 micras también se puede observar en la Figura 5b. La roca CNC pulida muestra un brillo negro excelente por la alta pureza de las fases de calcita fósiles, mientras que el color negro profundo es proporcionado por el kerógeno y óxidos de hierro-manganeso. Las superficies erosionadas y las secciones sin pulir muestran un color gris pálido diferente muy apreciado por los escultores para disponer de superficies de color diferente. Los bloques de CNC ya eran extraídos para escultura y arquitectura por los árabes españoles desde el año 400 d.C. Los productos de las canteras de Calatorao son pequeños bloques de caliza negra de hasta un metro cúbico, con pequeñas porosidades, grietas moderadas y vetas blancas de calcita, kerógeno y pirita accesoria.

\section{PROCESOS DE METEORIZACIÓN EN LAS ESCULTURAS}

El agujero recientemente abierto y cerrado en la cabeza de La Piedad muestra placas de CNC de $20 \mathrm{~cm}$ y un adhesivo blanco húmedo. Las estructuras estereotómicas ofrecen vía libre a las aguas de lluvia desde su construcción. El núcleo interno de La Piedad muestra hormigón descompuesto y morteros compuestos por fases hidratadas de portlandita, mirabilita, etringita y yeso. Las fases anhidras con estas mismas composiciones no fueron detectadas en las muestras analizadas. El yeso utilizado para pegar bloques de CNC y las aguas pluviales han generado grandes cantidades de etringita en el interior de la escultura. La alteración del hormigón y la presencia de etringita reducen mucho la cohesión interna de la escultura. Esta alteración también implica lixiviado de sodio de los feldespatos (7) de los áridos de granito y arcosa de la matriz del hormigón hacia los morteros sulfatados produciendo sulfatos cálcicos y sódicos muy corrosivos, incluyendo etringita y mirabilita. Uno de los mecanismos más importantes de descomposición de la cobertera rocosa exterior de las esculturas es la meteorización salina, que produce eflorescencias, y caídas de placas y fragmentos. (8-10). Los iones sulfato proceden principalmente de los morteros de la escultura pero también se generan por oxidación de la pirita interna de la CNC.
BLC sections demonstrate that it is a low porous rock; the porosity is 2.45 to $0.19 \%$ (Figure $5 b$ ). This geotechnical characteristics provide a good enough ornamental rock for architectural purposes to cut-polish little sculptures, to pave floors or to cover outside walls in temperate climates. The comparison between fresh (quarry) and weathered (sculpture flake) BLC, under the ESEM microscope, shows EDS analyses of near pure pyrite, i.e., $S$ and $\mathrm{Fe}$, in fresh BLC (Figure $5 b$ ) and just only Fe in the weathered case, i.e., iron oxo-hydroxide preserving the original framboidal structure characteristic pyrite formed in euxinic settings. The rounded shape of the quartz grains and pores size of circa $10 \mu \mathrm{m}$ can also be observed in Figure 5b. This rock polishes with excellent black luster by the high purity of the fossil calcite phases whilst the deep black color is mainly provided by kerogen and accessorial iron-manganese oxides. The weathered surfaces and unpolished sections show a dissimilar pale grey color very appreciated for the sculptors to produce colored variations of surfaces. The BLC have been mined all the times for sculptures and architectural purposes starting from the Spanish Arabs, e.g., 400 a.D. The stony products obtained in the Calatorao quarries are little rock blocks up to maxima of one cubic meter, with small porosity, moderate fissures and calcite white veins and accessorial content of sulfur and organic matter.

\section{WEATHERING PROCESSES IN THE SCULPTURES}

The examination of the recently open hole in The Piety sculpture shows BLC slabs of $20 \mathrm{~cm}$ and a white adhesive with moisture water. The stereotomic structures have fissures available to raining waters from the initial building time. The Piety sculpture core shows weathered concrete and joining blends composed by hydrous phases of portlandite, mirabilite, ettringite and gypsum. The anhydrous counterpart phases are totally absent of the concrete specimens analyzed. The extra gypsum used to join the BLC slabs and the rain waters keeps inside large amounts of ettringite. The concrete alteration associated to ettringite reduces its adhesive properties mainly to the internal iron structure. A consequence of this alteration is the sodium leaking from the feldspar aggregates of arkose sand, and granite aggregates of the concrete core (7) together with the surrounding sulfated blends forming corrosive sodium sulfates including ettringite and mirabilite. One of the most important decay mechanism in the rock and sculptures destruction of the external cover of BLC is salt weathering, which produces efflorescence, flaking and fall down of fragments. (8-10). Sulfate ions came mainly from the sculpture core and but also from the oxidation of accessorial pyrites also detected in the BLC slabs. Rain water percolates throughout the rock 
El agua de lluvia filtra a través de la porosidad y fisuras de roca CNC y morteros llegando al núcleo de hormigón, luego vuelven al exterior como soluciones salinas. El agua circulante entra en contacto a través de los bloques CNC entra en contacto con la materia orgánica interna. El pH de aguas en contacto con materia orgánica es ácido. El ácido sulfuroso es muy soluble en agua, e incluso a bajas concentraciones de dióxido de azufre, da lugar a agua ácida. La tasa de meteorización del feldespato es mayor si el agua contiene componentes agresivos, como $\mathrm{CO}_{2}$, sulfatos, protones provenientes de la oxidación de pirita, o ácidos orgánicos (por ejemplo, ácidos oxálico, fórmico y málico). La CNC contiene kerógeno interno y diferentes compuestos de materia orgánica, junto con hongos, líquenes y oxalatos formados en la superficie de la escultura. La erosión de los últimos cincuenta años ha producido ácidos carboxílicos que pueden disolver albita y cuarzo ya que simples ácidos orgánicos solubles en agua facilitan la solubilidad del feldespato, aumentan la velocidad de disolución y mantienen movilizado el Al en solución $(11,12)$. Los aniones de ácidos carboxílicos, tales como acetato y oxalato, son importantes agentes formadores de complejos que mejoran la movilidad del Al $(13,14)$. Aniones de ácidos carboxílicos y compuestos fenólicos son generados por la degradación del kerógeno (15). La alteración del hormigón funciona como un sistema de denudación de transporte limitado donde los productos de meteorización salen principalmente por fisuras produciendo las antiestéticas eflorescencias blancas externas de las esculturas. Las soluciones de meteorización entran primero en contacto con sus propios residuos y las concentraciones de solutos en los fluidos de salida tienden a ser bajas. Los sulfatos de calcio también atacan el hormigón directamente reaccionando con las fases hidro-alumino-silicatadas de la matriz. La presencia de sodio en el sistema acelera los procesos destructivos formando sales solubles sódicas con ciclos de recristalización e incrementos de presiones de cristalización en poros y fisuras tanto la CNC como en el hormigón. Los tiempos de cristalización de sales solubles en fisuras son cortos ya que se trata de lixiviados de aguas de lluvia formando placas y fisuras. El yeso es precursor del sulfato sódico porque ataca previamente a los feldespatos sódicos del hormigón formando sulfato sódico. Los ataques de los sulfatos con sus presiones de cristalización junto con la alteración de los feldespatos sódicos provocan serios deterioros de morteros y hormigones reduciendo la estabilidad mecánica de las esculturas. La alteración de la CNC exterior es grave y compleja y se relaciona con su mineralogía, petrología, geoquímica, propiedades petrofísicas, condiciones ambientales y las sales solubles en el mortero y en el hormigón interior. La alteración química de la CNC está estrechamente relacionada con la disolución de calcita producida por aguas ácidas. El pH de las aguas es débilmente ácido por la concentración de $\mathrm{CO}_{2}$ en la atmósfera tendiendo a bajar por la presencia fissures and joins mortars reaching the core concrete. It dissolves sulfates and transport $\mathrm{SO}_{4}{ }^{2-}$ ions back to the outer rock. Water drains throughout the BLC porosity comes into contact with the internal organic matter producing acids. The $\mathrm{pH}$ of water in contact with organic matter is generally acidic. Sulfurous acid is very soluble in water and even at low concentrations of sulfur dioxide or sulfurous acid it produces water acid. The rate of feldspar weathering is enhanced if the water contains aggressive components such as $\mathrm{CO}_{2}$, mineral acids (e.g. $\mathrm{H}^{+}$ produced in the pyrite oxidation) or organic acids (e.g. oxalic, formic and malic acids). The BLC contains internal kerogen and different compounds of organic matter together with fungi, lichens and oxalates formed in the sculpture surface. The slow weathering processes occurred during the last 50 years has produced carboxylic acids. Carboxylic acids play a role in the albite and quartz dissolution since simple water soluble organic acids facilitate feldspar solubility, dissolution rate and keeping mobilized the $A$ l in solution $(11,12)$. In particular, anions of carboxylic acids, such as acetate and oxalate, have become recognized as important complexing agents that may significantly enhance Al mobility $(13,14)$. Carboxylic acid anions and phenolic compounds are generated by kerogen degradation (15). The concrete weathering may be a transport-limited denudation regime in which the weathering products are leaking out mainly through the slabs joints producing visible unsightly white efflorescence in the sculptures. The weathering solutions primarily contact the residuals of weathering and the solute concentrations in the fluid streams tend to be low. Calcium sulfates could attack and destroy a concrete by reacting with the hydro-alumino-silicate phases of the hardened cement paste. The presence of sodium in the system speed up destructive processes forming soluble salts with re-crystallization cycles and additional crystallization pressures events in pores and fissures of the holding rock and concrete. The time in which soluble salts crystallize to the rock fissures tend to be short since they are leached by rain waters, although they are also found related to rock flaking and fissuring. Gypsum, ettringite and thaumasite salts are commonly associated with sulfate attacks and sodium sulfate related to both sulfate attack and alteration of sodium-feldspar aggregates. The sulfate attack, with crystallization pressure and alteration of feldspar aggregates provoke a severe mortar and concrete deterioration which play down to mechanical stability of the sculptures. The BLC alteration is severe and complex and is related to its mineralogical, geochemical, petrological and petro-physical properties; environmental conditions and soluble salts in the inner mortar and concrete. The chemical alteration of BLC is closely related to calcite dissolution by acid waters. The $\mathrm{pH}$ of waters is a weak acid solution defined by the concentration of atmospheric $\mathrm{CO}_{2}$ and tends to be lower by the presence of degradation products from organic 
de productos de degradación de materia orgánica, la oxidación de la pirita y por sulfatos internos. La oxidación de la pirita produce también manchas marrones que se pueden ver en planos de fisuras. La alteración física se produce por expansión térmica, hinchazón de la sal y cristalización del hielo. La CNC también puede presentar expansión hídrica por minerales de arcilla. La cristalización de sales y hielo en las grietas pre-existentes de la piedra caliza CNC las separa y las fragmenta, ampliando y uniendo fisuras preexistentes. La humedad relativa del aire de la zona es moderadamente alta con un valor anual promedio de $70 \%$, con un alto grado de estacionalidad y fluctuaciones a corto plazo en el verano. En terrenos de climas templados, como el observado en el Valle de los Caídos, son frecuentes las congelaciones y descongelaciones que producen la meteorización mecánica. La meteorización salina también contribuye a la descomposición mecánica producida por las heladas. Los ciclos disolución-cristalización de sales se suelen producir por aguas de lluvia o procesos de condensación (16-21). El sulfato sódico produce presiones de cristalización muy elevadas. Una restauración teórica de las Esculturas de Avalos debería eliminar los materiales incompatibles, es decir, los sulfatos, ello implicaría extracción de bloques $\mathrm{CNC}$, saneamiento del núcleo de hormigón afectado y recolocación de bloques de CNC. Las alternativas de sellado de fisuras de las esculturas con polímeros orgánicos mantendrían en el interior grandes cantidades de sulfatos y su posterior y segura degradación bajo la luz solar UV facilitaría nuevas entradas de aguas de lluvia y nuevas destrucciones de las esculturas en fragmentos más grandes unidos por polímeros. La gran dificultad de la restauración de las esculturas reside en la decisión equivocada de Juan de Avalos de utilizar morteros de yeso y áridos de granito con feldespatos sódicos junto con el enorme tamaño de las estructuras estereotómicas.

\section{CONCLUSIONES}

La exploración de la reciente perforación practicada en la escultura de La Piedad confirma que está recubierta por placas de $20 \mathrm{~cm}$ de CNC unidas con un mortero sulfatado hidratado compuesto por una mezcla de portlandita, mirabilita, etringita, taumasita y yeso, todas ellas fases peligrosas para el patrimonio construido. Las enormes estructuras estereotómicas permiten libre acceso a las aguas de lluvia. El núcleo interno de las esculturas es de hormigón con áridos de granito con feldespatos alcalinos sódicos que están liberando sodio y produciendo sulfatos sódicos y cálcicos como mirabilita y etringita. La CNC es porosa tiene cuarzo, piritas oxidadas y filosilicatos expansivos, como montmorillonita. La alteración química de la CNC se produce por disolución de calcita por aguas matter, pyrite oxidation and internal sulfates. The latter also produced a brownish-colored crust that is observed with a light-colored calcite crust in sheltered zones to the runoff of the sculptures. The physical alteration is produced by swelling and thermal expansion and salt and ice crystallization, which produce flaking and fissuring. The BLC may also present hygric expansion mainly due to the presence of clay minerals. The salt and ice crystallisation produced in pre-existing cracks of the limestone may contribute to the detachment and fragmentation process through the enlargement and coalescence of this kind of pre-existing fissures. The relative humidity of the air is moderately high with an average annual value of $70 \%$ showing a high level of seasonality and short-term fluctuations in summer. Temperate climates such as the case of the Valley of Fallen, with frequent freezing and thawing, are effective drivers of mechanical weathering. Salt weathering in the rock sculpture enhance the mechanical decay produced by frost action and crystallisation-dissolution cycles, where salt dissolution is produced by condensed and/or rain waters (1621). In the sodium sulphate system the dissolution of the lower hydrate and the precipitation of the hydrated salt leads to high crystallisation pressures. A theoretical restoration of the Avalos Sculptures removing the external incompatible building materials, i.e., sulfates, will be to remove the BLC blocks, to clean the sulfates, to scratch the weathered concrete outer, putting back again the blocks. Alternative soft proposals sealing the sculptures with organic polymers keeping inside large amounts of sulfates only will cause its degradation under the UV sunlight, new entrance of raining waters and further enhanced destruction of sculptures as bigger blocks. The strong difficult of the sculptures restoration stem from the wrong decision taken by Juan de Avalos to use internal gypsum and granite aggregates with sodium feldspars together with the huge size of the stereotomic structures.

\section{CONCLUSIONS}

The examination of the recently open pit in The Piety sculpture confirm us that it is covered by BLC slabs of $20 \mathrm{~cm}$ thick joined together with hydrous sulfated mortars composed by mixtures of portlandite, mirabilite, ettringite, thaumasite and gypsum all of them being dangerous hydrous phases for the built heritage. The huge stereotomic structures have open access to the raining waters. The internal core of the sculptures is concrete made with weathered alkali-feldspar aggregates providing sodium to the surrounding sulfated environment forming hydrous calcium sodium sulfates such as ettringite and mirabilite. The BLC is porous, has fissures with iron oxides, and contains pyrite and expansive phyllosilicates such as montmorillonite. The chemical alteration of 
ácidas producidas por pirita, materia orgánica y sobre todo sulfatos internos. La alteración física se produce por expansión térmica, hinchazón salina y cristalización del hielo produciendo gran cantidad fragmentos de roca CNC. Los ciclos de humedecimientos y secados explican las roturas de tensión de las superficies de piedra CNC junto con las grietas y descamaciones producidas por este proceso mecánico. La CNC de las esculturas sufre un deterioro progresivo que produce fisuras y pérdida de masa. Los daños por congelación son importantes en el Valle de los Caídos debido al elevado número de ciclos de congelación-descongelación que sufren las esculturas en un clima templado mediterráneo con una fuerte estacionalidad como la del Valle de los Caídos.

\section{AGRADECIMIENTOS}

Agradecemos el apoyo financiero de los proyectos nacionales CGL2008-04296, CGL2010-17108 y CGL200909247 del Plan Español Nacional de I + D + i. Damos las gracias a los escultores Capa, una empresa dedicada a la restauración y conservación de esculturas históricas y de la Agencia Española del Patrimonio Nacional por su ayuda durante la recolección de muestras en la restauración inicial de las obras de la escultura de La Piedad.
$B L C$ is closely related to calcite dissolution by acid waters produced by pyrite, organic matter and the internal sulfates. The physical alteration is produced by swelling and thermal expansion and salt and ice crystallization, which produce flaking and fissuring. Cycling processes could explain the stress development observed in stone surfaces during wetting and drying cycles and consequently the cracking and flaking formation resulting from this mechanical process. The sculpture stone is subjected to thermal deterioration, which produce rock fissuring and the progressive loss of grains. Frost damages are important in the Valley of the Fallen since an important number of freeze-thaw cycles have been produced during Sculptures' live. The climate in the Valley of the Fallen is temperate Mediterranean with strong seasonality.

\section{ACKNOWLEDGEMENTS}

We are grateful to projects CGL2008-04296, CGL201017108, and CGL2009-09247 of the Spanish Plan Nacional de $I+D+i$ for financial support. We thank to Capa Sculptors; a company devoted to the restoration and conservation of Historical Sculptures and to the Spanish National Heritage Agency for assisting us during the samples collection in the initial restoration works of The Piety Sculpture.

\section{BIBLIOGRAFÍA / BIBLIOGRAPHY}

(1) Zhang, Y.; Zeng, J.; Yu, B.: "Experimental study on interaction between simulated sandstone and acidic fluid", Petroleum Science, vol. 6 (2009), pp. 8-16. http://dx.doi.org/10.1007/s12182-009-0002-3

(2) Novak, G. A.; Colville, A. A.: "Efflorescence mineral assemblages associated with cracked and degraded residential concrete Foundation in Southern California", Cem. Concr. Res., vol. 19 (1989), pp. 1-6. http://dx.doi.org/10.1016/0008-8846(89)90059-8

(3) Irassar, E. F.; DiMaio, A.; Batic O. R.: "Sulfate attack on concrete with mineral admixtures", Cem. Concr. Res., vol. 26 (1996), pp. 113-123. http://dx.doi.org/10.1016/0008-8846(95)00195-6

(4) Damidot, D.; Glasser, F. P. Thermodynamic investigation of the $\mathrm{CaO}-\mathrm{SiO}_{2}-\mathrm{Al}_{2} \mathrm{O}_{3}-\mathrm{CaSO}_{4}-\mathrm{H}_{2} \mathrm{O}$ system at $25{ }^{\circ} \mathrm{C}$ and the influence of Na2O. Cem. Concr. Res., vol. 23 (1993), pp. 221-238. http://dx.doi.org/10.1016/0008-8846 (93)90153-Z

(5) Scherer, G. W.: "Crystallization in pores", Cem. Concr. Res., vol. 29 (1999), pp. 1347-1358. http://dx.doi.org/10.1016/S00088846(99)00002-2

(6) Brown, P. W.; Doerr, A.: "Chemical changes in concrete due to the ingress of aggressive species", Cem. Concr. Res., vol. 30 (2000), pp. 41-418. http://dx.doi.org/10.1016/S0008-8846(99)00266-5

(7) Roland, W.; Lei, C.: "Surface reactions during the early stages of weathering of albite", Geochimica et Cosmochimica Acta, vol. 568 (1992), pp. 3113-3121.

(8) Skalny, J.; Johansen, V.; Thaulow, N.; Palomo, A.: "DEF: As a form of sulfate attack". Mater. Construcc., vol. 46 (1996), pp. 5-29. http://dx.doi.org/10.3989/mc.1996.v46.i244.519

(9) Louis, M.; del Cura, M. A. G.; Spairani, Y., De Blas, D.: "The Civil Palaces in Gravina street, Alicante: building stones and salt weathering". Mater. Construcc., vol. 51 (2001), pp. 23-37.

(10) Martínez-Ramírez, S.; Blanco-Varela, M. T.: "Thermodinamically stable phases in the $\mathrm{CaO}-\mathrm{SiO}_{2}-\mathrm{Al}_{2} \mathrm{O}_{3}-\mathrm{CaSO}_{4}-\mathrm{H}_{2} \mathrm{O}$ closed system at 25 degrees C. Application to cementitious systems". Mater. Construcc., vol. 59 (2009), pp. 31-39.

(11) Franklin, S. P.; Hajash, A. J. R.; Dewers T. A.; Tieh T. T.: "The role of carboxylic acids in albite and quartz dissolution: An experimental study under diagenetic conditions", Geochimica et Cosmochimica Acta, vol. 58 (1994), pp. 4259-4279. http://dx.doi.org/10.1016/00167037(94)90332-8 
(12) Siebert, R. M.; Moncure, G. K.; Lahann, R. W.: "A theory of framework grain dissolution in sandstones" in McDonald, D. A., and Surdam, R. C. (eds.), Clastic diagenesis: American Association of Petroleum Geologists Bulletin, vol. 37 (1984), pp. 163-175.

(13) Surdam, R. C.; Crossey, L. J.; Lahamn, R.: "Mineral oxidants and porosity enhancement Conference: AAPG annual convention, San Antonio, TX, USA", American Association of Petroleum Geologists Bulletin, vol. 68 (1984), p. 532.

(14) Fein, J. B.: "Experimental-study of aluminum-oxalate complexing at $80^{\circ} \mathrm{C}$ - implications for the formation of secondary porosity within sedimentary reservoirs". Geology, vol. 19 (1991), pp. 1037-1040. http://dx.doi.org/10.1130/0091-7613(1991)019<1037:ESOAOC>2.3.CO;2

(15) Surdam, R. C.; Crossey, L. J.: "Organic-inorganic reactions during progressive burial - key to porosity and permeability enhancement and preservation". Philosophical Transactions of the Royal Society A, vol. 315 (1985), pp. 135-156. http://dx.doi.org/10.1098/ rsta.1985.0034

(16) Benavente, D.; Cueto, N.; Martínez-Martínez, J.; García-del-Cura, M. A.; Cañaveras, J. C.: "The influence of petrophysical properties on the salt weathering of porous building rocks". Environmental Geology, vol. 52 (2007), pp. 197-206. http://dx.doi.org/10.1007/ s00254-006-0475-y

(17) Dullien, F. A. L.; El-Sayed, M. S.; Batra, V. K.: "Rate of capillary rise in porous media with non-uniform pores", Journal of Colloid and Interface Science, vol. 60 (1977), pp. 497-506. http://dx.doi.org/10.1016/0021-9797(77)90314-9

(18) Benavente, D.; Lock, P.; García del Cura; M. A., Ordóñez, S.: "Predicting the capillary imbibition of porous rocks from microstructure". Transport in Porous Media, vol. 49 (2002), pp. 59-76. http://dx.doi.org/10.1023/A:1016047122877

(19) Cueto, N.; Benavente, D.; Martínez-Martínez, J.; García-del-Cura, M. A.: "Rock fabric, pore geometry and mineralogy effects on water transport in fractured dolostones", Engineering Geology, vol. 107 (2009), pp.1-15. http://dx.doi.org/10.1016/j.enggeo.2009.03.009 (20) Benavente, D.; Cultrone, G.; Gómez-Heras, M.: "The combined influence of mineralogical, hygric and thermal properties on the durability of porous building stones", European Journal of Mineralogy, vol. 20 (2008), pp. 673-685. http://dx.doi.org/10.1127/0935$1221 / 2008 / 0020-1850$

(21) Siegesmund, S.; Ullemeyer, K.; Weis, T.; Tschegg, E. K.: "Physical weathering of marbles caused by anisotropic thermal expansion". International Journal of Earth Science, vol. 89 (2000), pp .170-182. http://dx.doi.org/10.1007/s005310050324 